\title{
Two sides to every coin: farmers' perceptions of mining in the Maningory watershed, Madagascar
}

\author{
Natasha Stoudmann', Claude Garcial, I, Ihoby H. \\ Randriamalalal', Vanessa A. G. Rakotomalala"l', B. \\ Ramamonjisoalv
}

\author{
Correspondence: \\ Natasha Stoudmann \\ Forest Management and Development, Department of Environ- \\ mental Sciences, \\ Swiss Federal Institute of Technology Zurich \\ 8092 Zurich, Switzerland \\ Email: n.stoudmann@hotmail.com
}

\begin{abstract}
An increasing share of Madagascar's population is dependent on artisanal and small-scale mining (AMS) as a source of livelihood. However, this unregulated activity has numerous repercussions on the miners themselves and on neighboring communities. This study explores the perception of mining of those indirectly affected by its growing presence. Farmers and fishers were interviewed to better understand the perceived impacts of AMS on communities situated at varying distances from mining activity. The results of this first qualitative study show that positive or negative perception may be linked to geographical distance to mines. Those living in mining-communities may reap more benefits from the proximity than those living further away, who mainly experience negative effects. The results from this small sample will need to further be empirically tested.
\end{abstract}

\section{RÉSUMÉ}

Une part croissante de la population de Madagascar tire l'essentiel de ses moyens de subsistance de l'exploitation minière artisanale et à petite échelle. Cependant, cette activité nonréglementée a de nombreuses répercussions sur les mineurs euxmêmes et sur les communautés voisines. Cette étude explore comment les riverains indirectement touchés perçoivent l'exploitation minière qu'ils rencontrent de plus en plus souvent. Des paysans et des pêcheurs de communautés basées à des distances variées des activités minières ont été interviewés afin de mieux comprendre les impacts perçus de l'exploitation minière artisanale. Les résultats de cette première étude qualitative montrent que des perceptions positives ou négatives pourraient être liées à la distance entre les lieux de vie des communautés et les mines. Les habitants vivant au sein de communautés minières pourraient tirer plus de profit de cette proximité que ceux vivant plus loin et ressentant principalement des effets négatifs. Les résultats de ce premier échantillon devront être vérifiés de manière empirique.

\section{INTRODUCTION}

The extraction of Madagascar's mineral resources has been gaining momentum in the last few decades (Sarrasin 2007, Huff 2016, INSTAT 2016), attracting both large scale mining companies as well as an increasing number of fortune seekers looking for gems, forming a considerable large unregulated mining sector. These artisanal miners perform this activity without long-term planning and use simple extraction techniques (Hinton et al. 2003, Cardiff and Andriamanalina 2007, Gorenflo et al. 2011). Although the impacts of large scale mining (LSM) operations have often been des2014, Randriamamonjy et al. 2015), the social, economic and environmental impacts of artisanal and small scale mining (ASM) are often not so well documented and subject to increasing discussions due to its informal and often illegal nature (Hinton et al. 2003, Duffy 2007, Tilghman et al. 2007, Cook and Healy 2012). Although environmental and mining permits allowing ASM operations are issued by the authorities in Madagascar, much of the mining takes place without such permits having been obtained, with illegal extraction in protected areas being of key concern (Cook and Healy 2012, World Bank 2013). Previously depicted as an activity practiced by individuals to earn large amounts of cash in short amounts of time (World Bank 2005), there is a growing consensus surrounding the link between growth of artisanal mining and poverty, with ASM often being amongst the few alternative forms of livelihood diversification available to these individuals (Siegel and Veiga 2010, Canavesio 2014, Hilson 2016). It seems that more than opportunistic, engagement in ASM is more a result of lack of options, rather than a high risk/high reward strategy (Hilson 2010, Banchirigah and Hilson 2010, Canavesio 2014, Hilson 2016). Engaging in ASM often lead to increasing vulnerability, not the opposite (Cartier 2009).

The impacts of mining on Madagascar's natural environment are wide-ranging, from landscape changes, water pollution, to hunting of already scares animals (Tilghman et al. 2007, Gorenflo cribed (Harbinson 2007, Sarrasin 2007, Ballet and Randrianalijaona

\footnotetext{
I Forest Management and Development, Department of Environmental Sciences, Swiss Federal Institute of Technology Zurich, 8092 Zurich, Switzerland

॥ Forêts et Sociétés, CIRAD, Montpellier, France

III Madagascar Wildlife Conservation, Ambatondrazaka, Madagascar

IV University of Antananarivo, School of Agronomy, Water and Forest Department, BP 175, Antananarivo 101, Madagascar

Citation Stoudmann, N., Garcia, C., Randriamalala, I. H., Rakotomalala, V. A. G. and Ramamonjisoa, B. 2016. Two sides to every coin: farmers' perceptions of mining in the Maningory watershed, Madagascar. Madagascar Conservation \& Development 11, 2: 91-95. http://dx.doi.org.104314/mcd.v11i2.3
} 


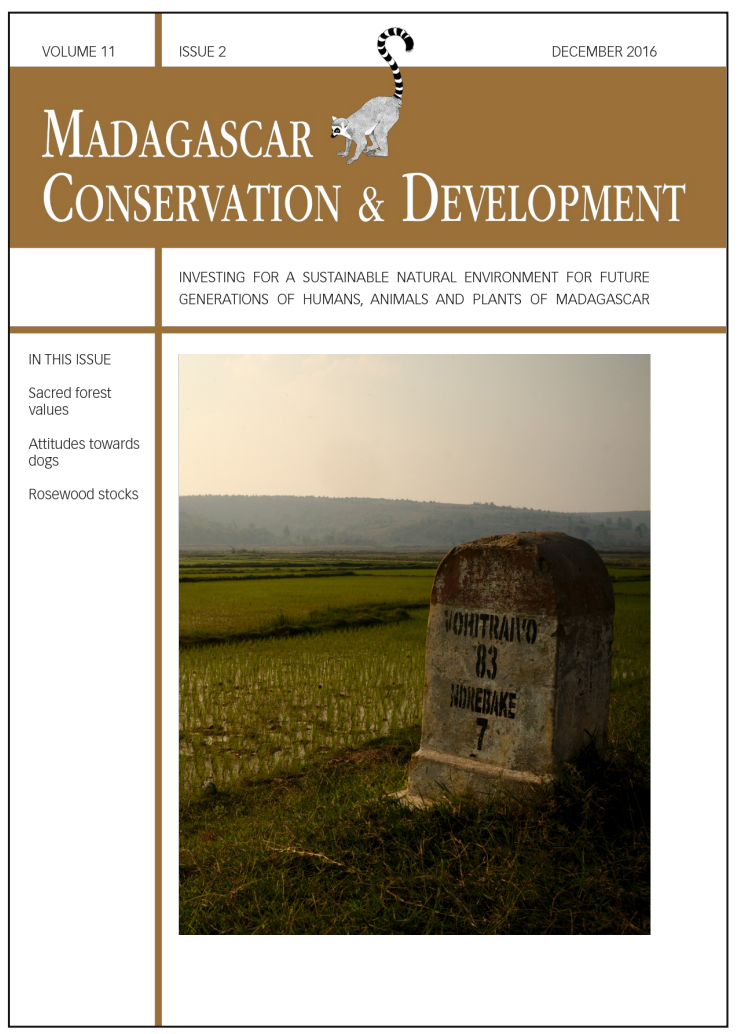

Madagascar Conservation \& Development is the journal of Indian Ocean e-Ink. It is produced under the responsibility of this institution. The views expressed in contributions to MCD are solely those of the authors and not those of the journal editors or the publisher.

All the Issues and articles are freely available at http://www.journalmcd.com

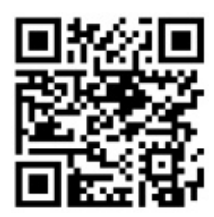

Contact Journal MCD

info@journalmcd.net for general inquiries regarding MCD funding@journalmcd.net to support the journal

Madagascar Conservation \& Development Institute and Museum of Anthropology

University of Zurich

Winterthurerstrasse 190

$\mathrm{CH}-8057$ Zurich

Switzerland

Indian Ocean e-Ink

Promoting African Publishing and Education

www.ioeink.com

Missouri Botanical Garden (MBG)

Madagascar Research and Conservation Program BP 3391

Antananarivo, 101, Madagascar 
et al. 2011), although it has been argued that impacts of ASM are restricted due to the localised nature of extraction (Cartier 2009). However, illegal mining taking place within national parks and other protected areas leading to the deterioration of local ecosystems is a source of concern for authorities and conservationists (Walsh 2004, Duffy 2005, Walsh 2013, Huff 2016).

Unlike large scale mining that has been supported by the Malagasy Government and the World Bank, ASM has commonly been negatively depicted by these institutions (World Bank 2005, Canavesio 2014). Although the World Bank (2015) is changing its standpoint, pushing for the formalisation of the ASM sector, these attempts have largely been put on the back burner by the new government instated in 2013 (Huff 2016).

Little information is available on the perception of ASM within local populations, and about the impacts that farmers - being the main resource users of Madagascar (Kull 2012, Rakotoarisoa et al. 2015) - view as stemming from this activity. Our study took place in the Maningory watershed, encompassing part of the AlaotraMangoro and Analanjirofo regions (Figure 1), from 27 October to 10 December 2015. As well as being agricultural hubs of the country (Andrianandrasana et al. 2005, Alizany et al. 2010), both regions are home to LSM and ASM activities, attracting an inflow of individuals and contributing to an increasing population (Raharinirina 2013, Rendigs et al. 2015, INSTAT 2016). We were interested in gaining a better understanding of the way farmers and fishers, two of the main resource users of these regions (Katila et al. 2014, Rakotoarisoa et al. 2015), experience mining. Our first research question focused on how these resource users perceive mining. secondly, we were interested in identifying the personal consequences they perceive as stemming from ASM.

\section{METHODOLOGY}

Our three study sites (Figure 1) were the villages of Antanandava, Vohimarina and Vavatenina, representing a transect of the Manin-

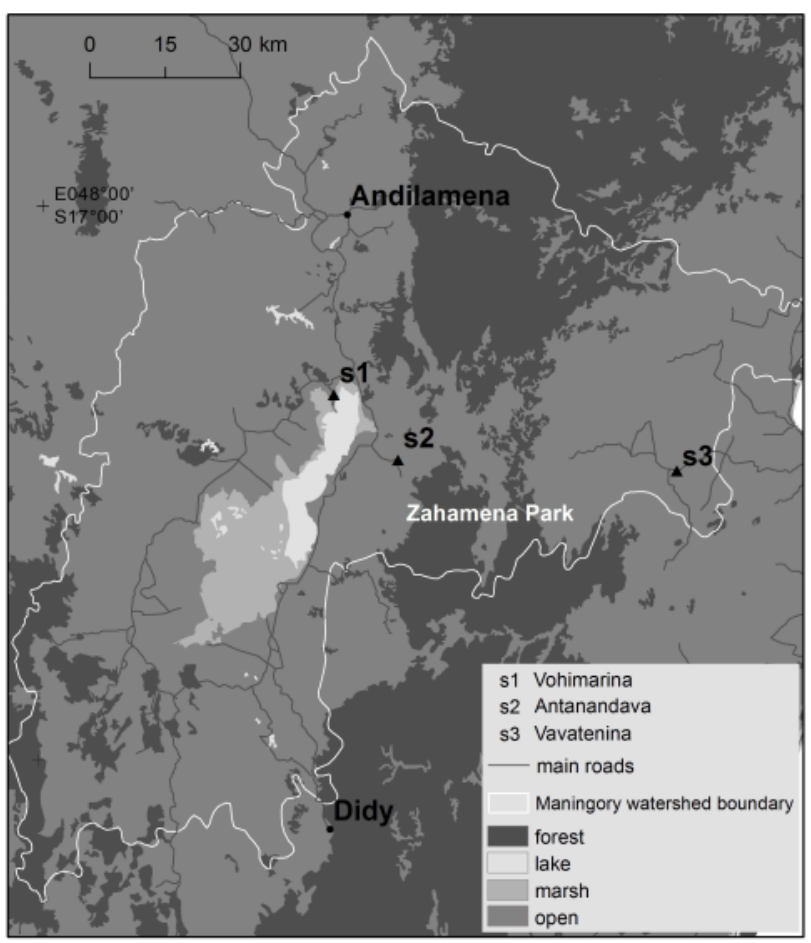

Figure 1. Delimitation of the Maningory watershed and location of the three study sites. Areas near Andilamena, Didy and Zahamena National Park are home to some of the most prominent mining sites in the region. gory watershed and being at varying distances from mining activity, the most prominent locations often mentioned by participants being in the regions of Didy, Andilamena, and several small sites near or within Zahamena National Park (Figure 1). Due to the informal nature of the mining, information about exact distances to the sites was not available.

Participants were selected per their profession (farmer and/or fisher), i.e., individuals who do not depend on mining as their main source of income, and age (between 25 and 65), with the aim of having a balanced representation of men and women. The subject of mining was identified as being relevant to farmers during a series of six focus group discussions (Kitzinger 1994) conducted in the three study sites (Figure 1) and comprised of a total of 30 participants. Having obtained the consent to interview the participants (Wilmé et al. 2016), these focus groups explored the broad subject of change, where mining and the extent of its impacts were often discussed. The notes taken during the focus groups were translated from Malagasy into French by a member of the research team having facilitated the discussions (A.R.), before being discussed and verified with the other members. Following this first phase of focus groups, we conducted 30 semi-structured interviews in the three study sites (10 per village, with $40.0 \%$ female respondents overall and $13.3 \%$ fishers). Participants were firstly asked whether they saw mining in a positive or negative light. Secondly, they were asked about the consequences of mining for themselves and their community. Each interview was translated as soon as possible after having been conducted from Malagasy into French (A.R.). We used the binomial test to determine whether there were significant sex, age, or profession differences in positive and negative views.

\section{RESULTS AND DISCUSSION}

The qualitative results of this small sample $(n=30)$ give an insight into farmers' perceptions and allow for the development of hypotheses that will need to be empirically tested. Although a quarter of participants perceived mining favourably, the remaining threequarters strongly believed this activity had negative effects for themselves and their community. Only one participant had a mixed view about the activity, pointing out both positive and negative impacts. There were no significant gender, age, or profession differences in terms of positive or negative views.

The participants identified 16 consequences of mining activities (Figure 2). The two most mentioned impacts relate to environmental effects of mining (soil degradation and forest degradation), which indirectly affect farmers' livelihoods and yields, as put forward by a participant: "(...) it leads to forest destruction which in turn leads to the absence of rain and waste covering fields, which leads to decreasing soil fertility" (P10). Several participants further put forward its direct impact on agriculture, as many male farmers try their luck searching for gems, leading to fewer people working the fields and therefore less produce available on the market. Participants mentioned that the attractiveness of becoming wealthy very fast pushed certain youngsters to drop out of school to work in the mines, often without their parents' consent, as one participant explained: "(...) children do not want to go to school anymore and drop out to go earn money at the mines" (P25).

Positive aspects were identified by $26.7 \%$ of participants, the most often mentioned being the increase in farmers' standard of living, as villages close to mining activities experienced increasing inflows of people. One participant explained the impact mines 


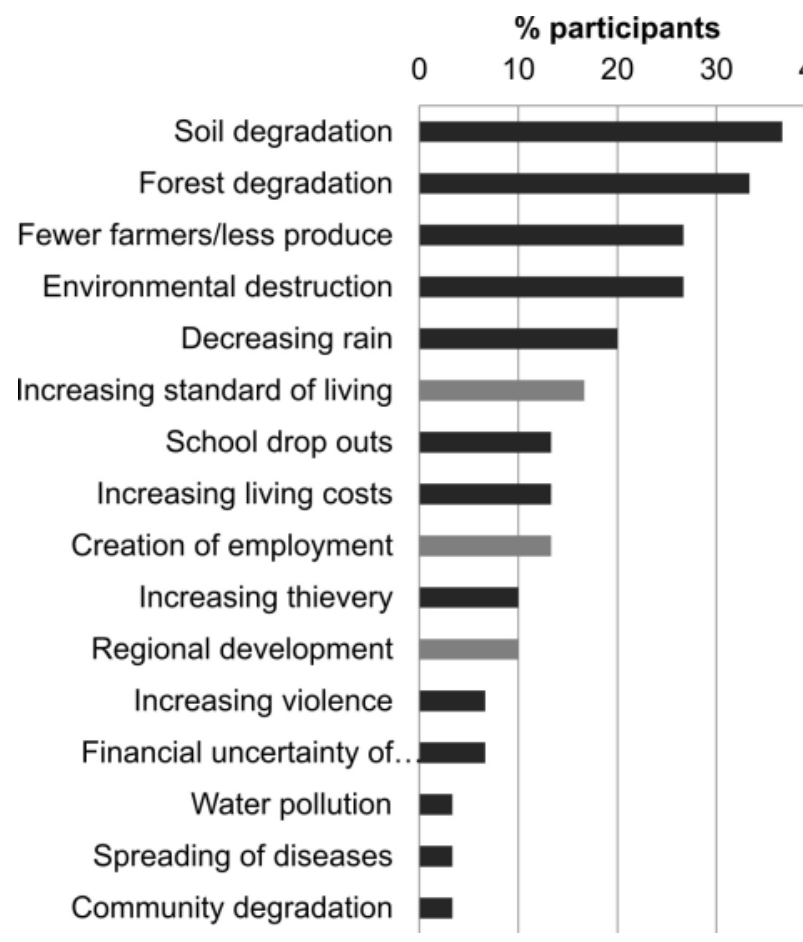

Figure 2. Consequences of mining identified by participants $(n=30)$. Positive identified aspects are in grey.

have had on him by "(...) the creation of work as a brick vendor, as there is an increasing number of people coming to the area" (P04). This can lead to a larger customer base and increasing opportunities for farmers to earn extra income. At a larger scale, this can be linked to employment creation and regional development, put forward by one participant, as mining activity "(...) increases my standard of living as my number of clients increases" (P08).

Figure 3 illustrates the geographical distribution of the positive and negative views between the three study sites. The village of Antanandava showed the highest percentage of support, whereas vavatenina the least. Although as previously stated exact distances to mines were not available, Antanandava is known for its proximity to mines and is the gateway to the Zahamena National Park (Figure 1), where rumours of gold mining are commonplace throughout the region, also having been mentioned by several participants.

The sample shows that there may be a geographical relation between support and opposition towards mining activities. We hypothesise that support or opposition to mining may be linked to a village's distance to the activity, with villages that are closer reaping more benefits such as larger client bases, whereas villages further away experience the negative impacts such as farmers leaving to go to the mines, without having any of the potential po-

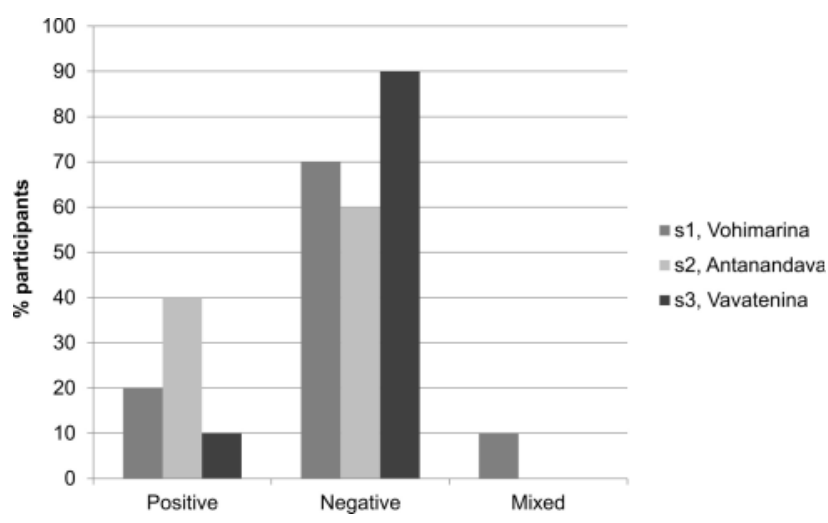

Figure 3. Geographical distribution of positive and negative views. sitive impacts reaching them. Mining communities, i.e. villages where a significant share of its population work in mining and where extracted commodities are sold (Cartier 2009), may therefore have more positive views of the activity than non-mining communities, where different - mostly negative - impacts of this activity are felt.

The consequences of mining identified by participants are closely linked to changes they generally see as affecting them, connected to environmental and agricultural issues affecting the livelihoods of these populations (Banchirigah and Hilson 2010, Rakotoarisoa 2015). Socio-economic impacts are also emphasised, although to a lesser extent. This could imply that when considering quality of life, farmers attribute most value to securing their livelihood (Scoones 1998), with other factors seen as being secondary to their well-being. Bebbington (1999) puts forward the importance of social capital relative to the other four capital assets - namely natural, human, cultural, and produced capital stating that this asset plays a key role in determining rural people's livelihoods, in that it "facilitates forms of action that one would expect enhance peoples' livelihoods" (Bebbington 1999: 2037). In the case of mining, this could imply that the social interactions and assets derived from these, both for miners and for those living within the mining community, lead to improved livelihoods even if at the cost of for example natural capital. The increase in social capital could be brought about for example through increased interactions due to the flow of people coming and going through the village. Environmental issues will directly affect farmers' livelihoods, however farmers who are also indirectly benefiting from ASM - or directly if they partake in mining as a secondary activity - may have their natural capital assets decreased, but their access to another form of capital improved. Thus, although those whose livelihoods have improved through the development of this activity will perceive it favourably, those whose capitals and therefore livelihood have been negatively affected, even indirectly and/or from a distance, will have a negative stance towards the subject. These hypotheses would however need to be tested with a larger sample.

\section{CONCLUSION}

This first qualitative exploration of perception of ASM of those indirectly affected by it, also being the main resource users of the Maningory watershed, gives a first insight into how this activity may be unevenly affecting communities of these regions. Further research is needed to better understand how mining impacts the quality of life both of its workers and of mining community inhabitants working in the agricultural sector. Furthermore, little is known about the factors pushing farmers of the Alaotra to change their life-long trade and enter the mining sector - whether they do so as a form of opportunity to 'get rich quick', or out of necessity and on a long-term basis, as a form of diversification. It is first necessary to understand the nature of ASM and the perceptions of those living with and around it to gain a better understanding about how to potentially improve the management of this growing activity and its many consequences. 


\section{ACKNOWLEDGEMENTS}

We would like to thank the personnel of Madagascar Wildlife Conservation for their support throughout the fieldwork, as well as the participants for their time. A special thanks goes to Patrick O. Waeber for his comments on an early draft, as well as to the reviewers for their help in improving this piece. This work was supported by the Swiss Programme for Research on Global Issues for Development under the research grant IZ01Z0_146852.

\section{REFERENCES}

Alizany, N., Chrysostôme Rakotondravelo, J., Rabarijohn, R., Raharinjanahary, H., Rabeharisoa, L., et al. 2010. Adapting to cyclones in Madagascar's Analanjirofo region. Adaptation Insights: addressing climate change in Africa through participatory action research 7. Center for International Forestry Research, Bogor Barat. Available at <https://www.idrc.ca/sites/default/files/sp/Documents\%20EN/idrc-adaptation-insight-madagascar-adapting-to-cyclones.pdf>

Andrianandrasana, H. T., Randriamahefasoa, J., Durbin, J., Lewis, R. E. and Ratsimbazafy, J. H. 2005. Participatory ecological monitoring of the Alaotra wetlands in Madagascar. Biodiversity \& Conservation 14, 11: 2757-2774. (doi:10.1007/s10531-005-8413-y)

Ballet, J. and Randrianalijaona, M. 2014. A case study on human development and security: Madagascar's mining sector and conservation-induced displacement of populations. Journal of Global Ethics 10, 2: 216-230. (doi:10.1080/17449626.2014.935458)

Banchirigah, S. M. and Hilson, G. 2010. De-agrarianization, re-agrarianization and local economic development: Re-orientating livelihoods in African artisanal mining communities. Policy Sciences 43, 2: 157-180. (doi:10.1007/s11077009-9091-5)

Bebbington, A. 1999. Capitals and capabilities: a framework for analyzing peasant viability, rural livelihoods and poverty. World Development 27, 12: 2021-2044. (doi:10.1016/S0305-750X(99)00104-7)

Canavesio, R. 2014. Formal mining investments and artisanal mining in southern Madagascar: Effects of spontaneous reactions and adjustment policies on poverty alleviation. Land Use Policy 36: 145-154. (doi:10.1016/j.landusepol.2013.08.001)

Cardiff, S. G. and Andriamanalina, A. 2007. Contested spatial coincidence of conservation and mining efforts in Madagascar. Madagascar Conservation \& Development 2, 1: 28-34. (doi:10.4314/mcd.v2i1.44127)

Cartier, L. E. 2009. Livelihoods and production cycles in the Malagasy artisanal ruby-sapphire trade: a critical examination. Resources Policy 34, 1-2: 80-86. (doi:10.1016/j.resourpol.2008.02.003)

Cook, R. and Healy, T. 2012. Madagascar Case Study: Artisanal Mining Rushes in Protected Areas and a Response Toolkit. World Wide Fund for Nature and Estelle Levin, Ltd. Available at <https://portals.iucn.org/library/sites/library/files/documents/Bios-Cons-Nat-Pro-691-008.pdf>

Duffy, R. 2005. Global environmental governance and the challenge of shadow states: the impact of illicit sapphire mining in Madagascar. Development and Change 36, 5: 825-843. (doi:10.1111/j.0012-155X.2005.00437.X)

Duffy, R. 2007. Gemstone mining in Madagascar: transnational networks, criminalisation and global integration. Journal of Modern African Studies 45, 2 : 185-206. (doi:10.1017/S0022278X07002509)

Gorenflo, L. J., Corson, C., Chomitz, K. M., Harper, G., Honzák, M. and Özler, B. 2011. Exploring the association between people and deforestation in Madagascar In: Human Population: Its Influences on Biological Diversity, Ecological Studies 214. R. P. Cincotta and L. J. Gorenflo (eds.), pp 197-221. Springer-Verlag, Heidelberg. (doi:10.1007/978-3-642-16707-2_11)

Harbinson, R. 2007. Development Recast? A Review of the Impact of the Rio Tinto Ilmenite Mine in Southern Madagascar. Report for Friends of the Earth, Panos London. Available at <https://www.foe.co.uk/sites/default/files/downloads/development_recast.pdf>

Hilson, G. 2010. 'Once a miner, always a miner': poverty and livelihood diversification in Akwatia, Ghana. Journal of Rural Studies 26, 3: 296-307. (doi:10.1016/j.jrurstud.2010.01.002)
Hilson, G. 2016. Farming, small-scale mining and rural livelihoods in Sub-Saharan Africa: a critical overview. The Extractive Industries and Society 3, 2: 547-563. (doi:10.1016/j.exis.2016.02.003)

Hinton, J. J., Veiga, M. M. and Veiga, A. T. C. 2003. Clean artisanal gold mining: a utopian approach? Journal of Cleaner Production 11, 2: 99-115. (doi:10.1016/S0959-6526(02)00031-8)

Huff, A. 2016. Black Sands, Green Plans and Conflict: Structural Adjustment, Sectoral Reforms and the Mining-Conservation-Conflict Nexus in Southern Madagascar. Institute of Development Studies Report 183, Brighton. Available at $<$ goo.gl/TYKOIn>

Institut National de la Statistique (INSTAT). 2016. <http://www.instat.mg/> accessed 28 July 2016

Katila, P., Galloway, G., de Jong, W., Pacheco, P. and Mery, G. (eds.) 2014. Forests Under Pressure: Local Responses to Global Issues. International Union of Forest Research Organisation, Vantaa. Available at <http://www.cifor.org/publications/pdf_files/Books/BPacheco1401.pdf >

Kitula, A. G. N. 2006. The environmental and socio-economic impacts of mining on local livelihoods in Tanzania: a case study of Geita District. Journal of Cleaner Production 14, 3-4: 405-414. (doi:10.1016/j.jclepro.2004.01.012)

Kitzinger, J. 1994. The methodology of focus groups - the importance of interaction between research participants. Sociology of Health \& Illness 16, 1 : 103-121. (doi:10.1111/1467-9566.ep11347023)

Kull, C. A. 2012. Air photo evidence of historical land cover change in the highlands: wetlands and grassland give way to crops and woodlots. Madagascar Conservation \& Development 7, 3: 144-152. (doi:10.4314/mcd.v7i3.7)

Raharinirina, V. 2013. Conflits "glocaux" autour des Projets Extractifs et Agraires à Madagascar. État des Résistances dans le Sud : les Mouvements Paysans. Alternatives Sud, Belgium 20, 4: 57-66.

Rakotoarisoa, T. F., Waeber P. O., Richter, T. and Mantilla-Contreras, J. 2015. Water hyacinth (Eichhornia crassipes), any opportunities for the Alaotra wetlands and livelihoods? Madagascar Conservation \& Development 10, S3: 128-136. (doi:10.4314/mcd.v10i3.5)

Randriamamonjy, V. C., Keane, A., Razafimanahaka, H. J., Jenkins, R. K. B. and Jones, J. P. G. 2015. Consumption of bushmeat around a major mine, and matched communities, in Madagascar. Biological Conservation 186: 35-43. (doi:10.1016/j.biocon.2015.02.033)

Rendigs, A., Reibelt, L. M., Ralainasololo, F. B., Ratsimbazafy, J. H. and Waeber, P. O. 2015. Ten years into the marshes - Hapalemur alaotrensis conservation, one step forward and two steps back? Madagascar Conservation \& Development 10, 1s: 13-20. (doi:10.4314/mcd.v10i1.s3)

Sarrasin, B. 2007. Le projet minier de QIT Madagascar Mineral à Tolagnaro (FortDauphin, Madagascar) : quels enjeux de développement ? Afrique Contemporaine 221: 205-223. (doi:10.3917/afco.221.0205)

Scoones, I. 1998. Sustainable Rural Livelihoods: A Framework for Analysis. IDS working paper 72. University of Sussex, Brighton. Available at <https://www.staff.ncl.ac.uk/david.harvey/AEF806/Sconnes1998.pdf>

Siegel, S. and Veiga, M. M. 2010. The myth of alternative livelihoods: artisanal mining, gold and poverty. International Journal of Environment and Pollution 41, 3-4: 272-288. (doi:10.1504/JJEP.2010.033236)

Tilghman, I., Baker, M. and DeLeon, S. D. 2007. Artisanal Sapphire Mining in Madagascar: Environmental and Social Impacts. Tiffany and Co. Available at <http://www.uvm.edu/rsenr/gemecology/assets/Tilghman_et_al_Madagascar_2005.pdf >

Walsh, A. 2004. In the wake of things: speculating in and about sapphires in Northern Madagascar. American Anthropologist 106, 2: 225-237. (doi:10.1525/aa.2004.106.2.225)

Walsh, A. 2013. Parenting through boom and bust in a northern Malagasy mining town. In: Contest for Land in Madagascar: Environment, Ancestors and Development. S. Evers, G. Campbell and M. Lambek (eds.). African Social Studies Series 31: 171-186. (doi:10.1163/9789004256231_009)

Wilmé, L., Waeber, P. O., Moutou, F., Gardner, C. J., Razafindratsima, O., et al. 2016. A proposal for ethical research conduct in Madagascar. Madagascar Conservation \& Development 11, 1: 36-39. (doi:10.4314/mcd.v11i1.8) 
World Bank. 2005. The Millennium Development Goals and small-scale mining: a conference for forging partnership for action. Workshop report. The World Bank, Washington D.C. Available at <http://www.ddiglobal.org/login/resources/mdgs-and-small-scale-mining.pdf>

World Bank. 2013. Madagascar - Country Environmental Analysis (CEA): taking stock and moving forward. The World Bank, Washington D.C. Available at <http://documents.worldbank.org/cura-

ted/en/599641468054534317/pdf/779930WPOMDG0C00Box377320B00PUBLICO.pdf>

World Bank. 2015. Economic contribution from industrial Mining in Madagascar: research Summary. The World Bank, Washington D.C. Available at $<$ http://documents.worldbank.org/cura-

ted/en/263731468179369566/pdf/100345-WP-P131522-mining-researchsummary-Box393222B-PUBLIC-ENG.pdf> 